\title{
Water-Quality Comparison of the Gulf Coast Aquifer System at Various Scales in Texas From National Water-Quality Assessment Groundwater Studies, 2013-15
}

One of the objectives of the U.S. Geological Survey National Water-Quality Assessment (NAWQA) Project is to assess groundwater quality in aquifers that are important sources of drinking water (DeSimone and others, 2014) such as the coastal lowlands aquifer system, which is often referred to in Texas as the "Gulf Coast aquifer system" (fig. 1). The Gulf Coast aquifer system extends from Louisiana to Mexico and is a source of groundwater for several cities including Houston, Tex. (Ryder, 1996; Braun and others, 2019). The NAWQA groundwater studies in Texas in 2013-15 that assessed the Gulf Coast aquifer system included Principal Aquifer Surveys (PAS), Major Aquifer Studies (MAS), and Land Use Studies (LUS). These three study types are based on sampling networks of wells distributed in an area of interest. The PAS networks typically consist of publicsupply wells that are relatively deep, the MAS networks typically consist of domestic-supply wells that are intermediate in depth, and the LUS networks typically consist of monitoring wells that are relatively shallow (DeSimone and others, 2014).

The Gulf Coast aquifer system is mostly composed of unconsolidated to poorly consolidated sediments of Miocene age and younger that include three depositional environments: continental (alluvial plain), transitional (delta, lagoon, and beach), and marine (continental shelf). A fluvial-deltaic wedge of discontinuous beds of sand, silt, and clay sediments was deposited in bands that parallel the Gulf of Mexico coast (Ryder, 1996). This wedge of unconsolidated to poorly consolidated sediments increases in thickness and depth toward the gulf (Ryder, 1996). Coarser grained nonmarine deposits that occur updip (within the aquifer system) grade laterally into finer grained material that was deposited downdip in marine environments (Ryder, 1996; Oden and Szabo, 2015). The Gulf Coast aquifer system consists of the Chicot aquifer, Evangeline aquifer, Burkeville confining unit, Jasper aquifer, and Catahoula Sandstone (Oden, 2011). The Chicot aquifer and the underlying Evangeline aquifer are hydraulically connected and not separated by a distinct confining unit; they are identified by a gradational decrease in grain size with depth (Oden, 2011). The Chicot and Evangeline aquifers are the primary sources of groundwater used for drinking water by the City of Houston (Oden and Szabo, 2015).

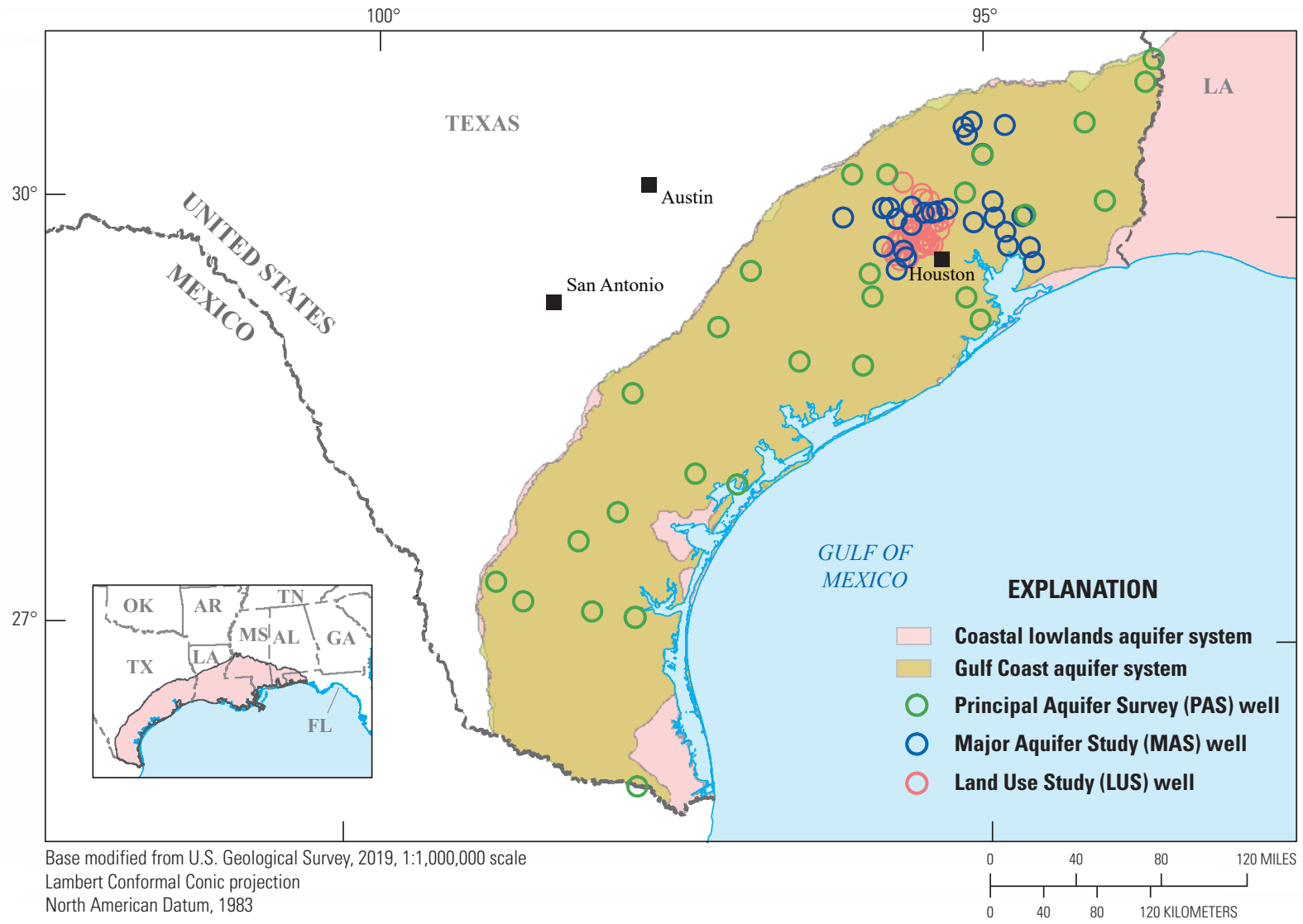

Figure 1. Groundwater well networks sampled in the Gulf Coast aquifer system in Texas in 2013-15. 


\section{Overview of Water-Quality Sampling and Benchmarks for Evaluating Groundwater Quality}

The network of public-supply wells in the Gulf Coast aquifer system was sampled to assess groundwater quality in parts of the aquifer system deeper than those tapped by domestic wells. These public-supply wells were sampled as part of the PAS in 2013 for basic water-quality properties (such as dissolved oxygen, $\mathrm{pH}$, specific conductance, temperature, and turbidity), major ions, nutrients, organic carbon, trace elements, select age-dating tracers, radionuclides, and an extensive suite of pesticides, volatile organic compounds (VOCs), pharmaceuticals, and hormones. The MAS assessed groundwater quality in parts of the aquifer tapped primarily by domestic or private supply wells, which were sampled in 2014. The LUS assessed the effects of specific land uses (in this case, urban) on shallow groundwater quality by sampling the monitoring well network in 2015. The MAS and LUS networks tend to be nested within the PAS network for a more complete understanding of aquifer conditions to help support regional and national modeling efforts. All three networks (PAS, MAS, and LUS) were sampled for the same analytes, and water-quality results were compared to preestablished benchmarks for drinking water (fig. 2) to provide context for evaluating the quality of untreated



Figure 2. Example graph for concentrations compared to human-health benchmarks.

groundwater (Norman and others, 2018). The data collected by the NAWQA Project include chemical analyses generally not available as part of regulatory compliance monitoring, including measurements at concentrations much lower than human-health benchmarks and measurements of analytes that can be used to trace the sources and movement of groundwater.

\section{Water-Quality Results for the Gulf Coast Aquifer System}

Groundwater samples from wells completed in the Gulf Coast aquifer system were analyzed for inorganic constituents (such as dissolved solids, nutrients, and trace elements), radionuclides (such as gross alpha and beta activity), and organic compounds (DeSimone and others, 2014). Many inorganic constituents are naturally present in groundwater. The concentrations of inorganic constituents can be affected by natural processes and by human activities and can affect the aesthetic properties of water or can create nuisance problems, such as staining and scaling. The benchmark used for dissolved solids is a nonregulatory secondary maximum contaminant level established for drinking water (Norman and others, 2018). Dissolved-solids concentration is a measure of the salinity of the groundwater based primarily on the concentrations of major ions and can affect aesthetic properties such as taste (fig. 3). All water naturally contains dissolved solids from weathering and dissolution of minerals in rocks and sediments, but some of the dissolved solids in water can result from human activities, such as fertilizer applications to land surface (Hem, 1985). Elevated dissolved-solids concentrations in groundwater may reflect longer residence times from deeper wells (Oden and Szabo, 2015).

B

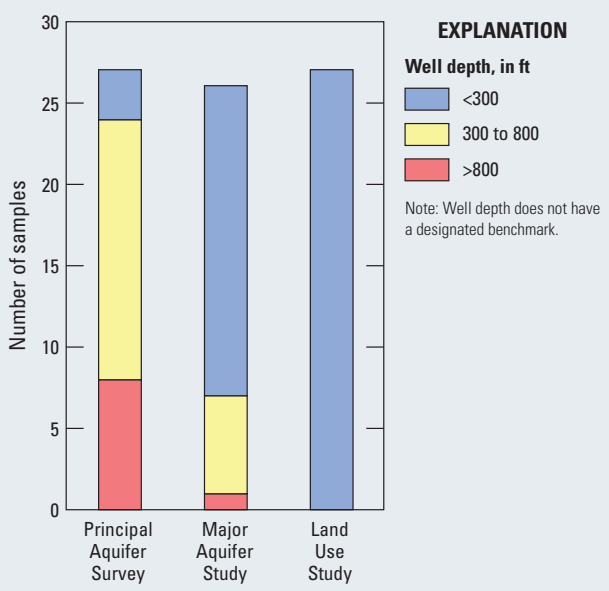

Figure 3. $A$, Dissolved-solids concentrations in milligrams per liter (mg/L) and $B$, well depth in feet ( $\mathrm{ft}$ ) for groundwater sampled in the Gulf Coast aquifer system in Texas. 


\section{Nutrients}

Nutrients, such as nitrate, nitrite, and phosphorus, are naturally present at low concentrations in groundwater (less than one-half of human-health benchmarks); moderate or high concentrations (relative to human-health benchmarks) usually result from human activities (DeSimone and others, 2014). Groundwater samples collected from wells completed in the Gulf Coast aquifer system were analyzed for five nutrients, of which two (nitrate and nitrite) have human-health benchmarks (Norman and others, 2018). Common sources of nutrients, aside from soils, include fertilizer applied to crops and landscaping, seepage from septic systems, and human and animal waste (Hem, 1985). Analysis results for nitrogen in groundwater included nitrate plus nitrite concentrations. Because most of the nitrite concentrations were below detection limits ( 0.04 milligrams per liter), most of the nitrogen occurs as nitrate in the Gulf Coast aquifer system (fig. 4) (Arnold and others, 2016, 2017, 2018).

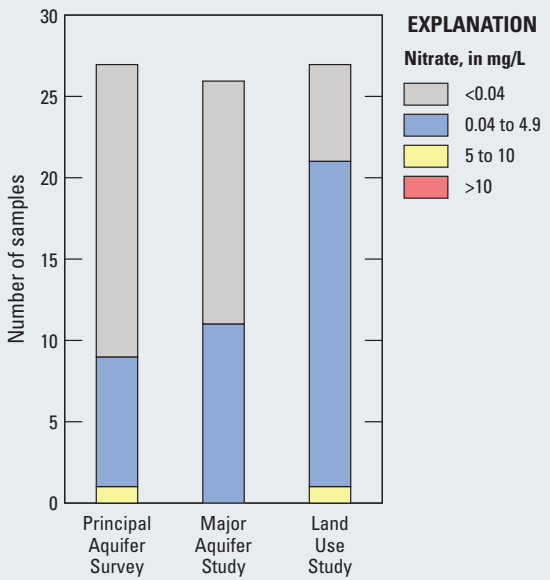

Figure 4. Nitrate concentrations in milligrams per liter (mg/L) for groundwater sampled in the Gulf Coast aquifer system in Texas.

\section{Trace Elements}

Trace elements, such as arsenic, manganese, and chromium, are naturally present in the minerals of rocks, soils, and sediments and in the water that interacts with those materials, although the concentrations of some trace elements can be affected by human activities (Hem, 1985). Groundwater samples collected from wells completed in the Gulf Coast aquifer system were analyzed for
A

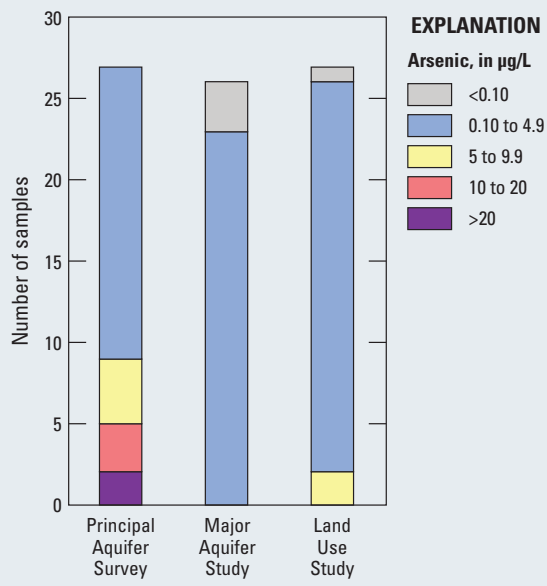

B

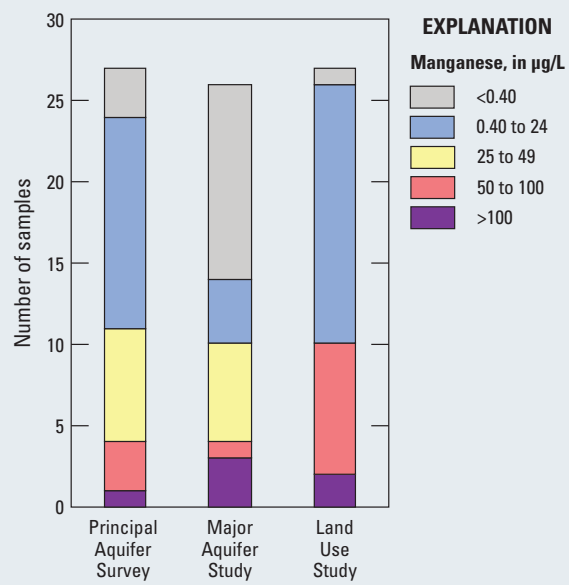

34 trace elements, of which 19 have human-health benchmarks (Norman and others, 2018). Arsenic and manganese were the only trace elements detected at concentrations that exceeded established human-health benchmarks (fig. 5) (Arnold and others, 2016, 2017 , 2018). Chromium was not detected at moderate or high concentrations but was detected in numerous samples and is a trace element of concern in areas with many industrial activities (Hem, 1985; Arnold and others, 2016, 2017, 2018).
Figure 5. $A$, Arsenic, $B$, manganese, and $C$, chromium concentrations in micrograms per liter $(\mu \mathrm{g} / \mathrm{L})$ for groundwater sampled in the Gulf Coast aquifer system in Texas.
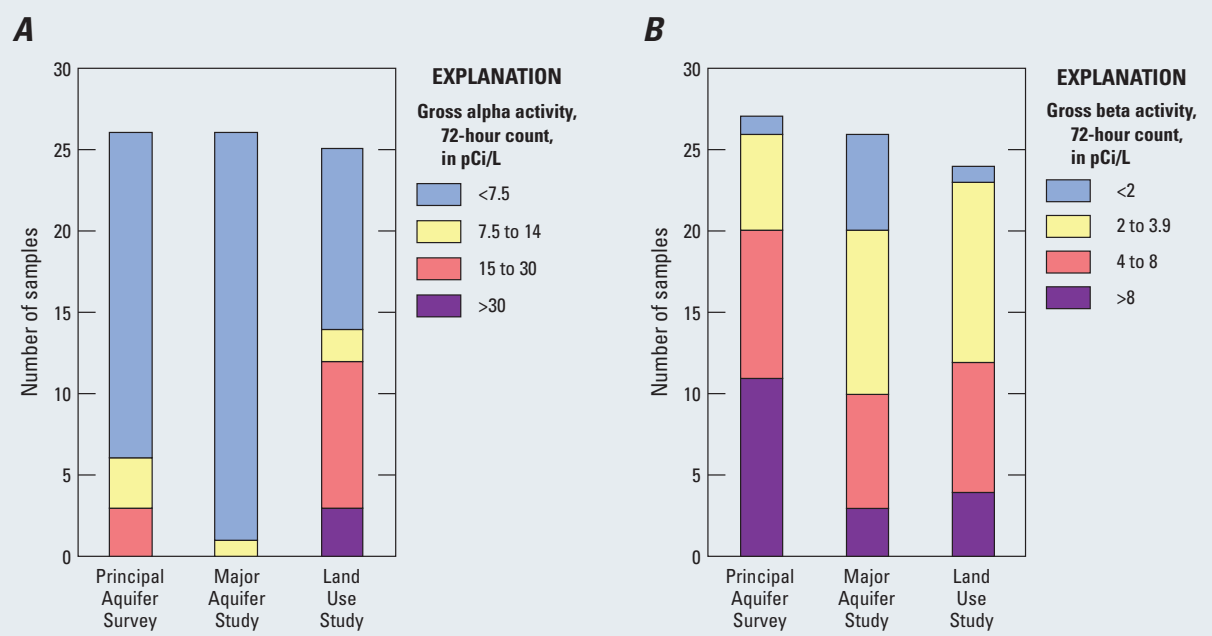

\section{Radionuclides}

Radioactivity is the release of energy or energetic particles during the spontaneous decay of unstable atoms (radionuclides). Humans are continuously exposed to small amounts of natural radioactivity. Most of the radioactivity in groundwater comes from the decay of isotopes of uranium and thorium that are naturally present in minerals in aquifer materials (Hem, 1985). Groundwater samples collected from wells completed in the Gulf Coast aquifer system were analyzed for eight radionuclides, four of which have humanhealth benchmarks (Norman and others, 2018). Gross alpha and beta activity were the only radionuclides detected at concentrations that exceeded established human-health benchmarks (fig. 6) (Arnold and others, 2016, 2017, 2018). 


\section{Organic Compounds}

Organic compounds derived from human activities are found in household, business, industrial, and agricultural products and can enter the environment through normal usage, spills, or improper disposal. Many organic compounds are commonly detected in surface water and bed sediments in urban, suburban, and agricultural areas (Battaglin and others, 2018). Organic compounds that were analyzed in groundwater samples collected from wells completed in the Gulf Coast aquifer system included VOCs, pesticides, pharmaceuticals, and hormones (DeSimone and others, 2014). Many of these organic compounds do not have established human-health benchmarks, but none of the concentrations measured in groundwater samples collected from wells completed in the Gulf Coast aquifer system exceeded any established humanhealth benchmarks for organic compounds (fig. 7) (Norman and others, 2018; Arnold and others, 2016, 2017, 2018).

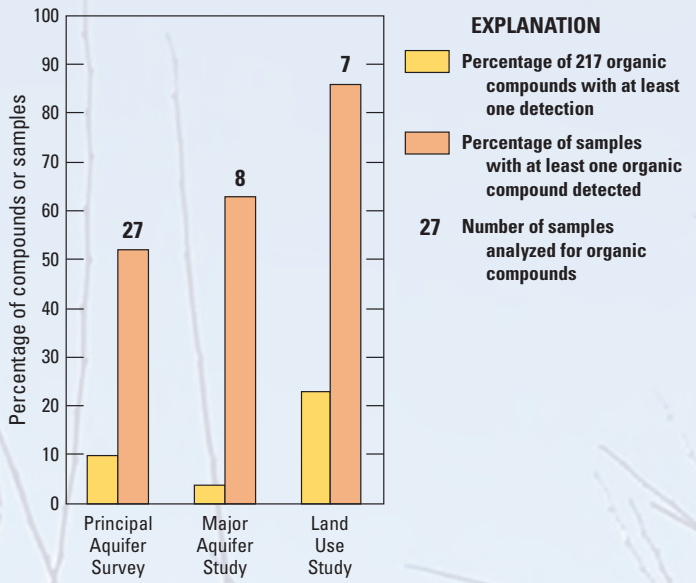

Figure 7. Percentage of organic compounds detected and percentage of samples with organic compound detections in groundwater sampled in the Gulf Coast aquifer system in Texas.

\section{References Cited}

Arnold, T.L., Bexfield, L.M., Musgrove, M., Lindsey, B.D., Stackelberg, P.E., Barlow, J.R., DeSimone, L.A., Kulongoski, J.T., Kingsbury, J.A., Ayotte, J.D., Fleming, B.J., and Belitz, K., 2017, Groundwater-quality data from the National Water-Quality Assessment Project, January through December 2014 and select quality-control data from May 2012 through December 2014: U.S. Geological Survey Data Series 1063, 83 p., accessed October 21, 2019, at https://doi.org/10.3133/ds1063.

Arnold, T.L., Bexfield, L.M., Musgrove, M., Stackelberg, P.E., Lindsey, B.D., Kingsbury, J.A., Kulongoski, J.T., and Belitz, K., 2018, Groundwater-quality and select quality-control data from the National Water-Quality Assessment Project, January through December 2015, and previously unpublished data from 2013 to 2014: U.S. Geological Survey Data Series 1087, 68 p., accessed October 21, 2019, at https://doi.org/10.3133/ds1087.

Arnold, T.L., DeSimone, L.A., Bexfield, L.M., Lindsey, B.D., Barlow, J.R., Kulongoski, J.T., Musgrove, M., Kingsbury, J.A., and Belitz, K., 2016, Groundwater quality data from the National Water-Quality Assessment Project, May 2012 through December 2013: U.S. Geological Survey Data Series 997, 56 p., accessed October 21, 2019, at http://dx.doi.org/10.3133/ds997.

Battaglin, W.A., Bradley, P.M., Iwanowicz, L., Journey, C.A., Welsh, H.L., and Blazer, V.S., 2018, Pharmaceuticals, hormones, pesticides, and other bioactive contaminants in water, sediment, and tissue from Rocky Mountain National Park, 2012-2013: Science of the Total Environment, v. 643, p. 651-673.

Braun, C.L., Ramage, J.K., and Shah, S.D., 2019, Status of groundwater-level altitudes and long-term groundwaterlevel changes in the Chicot, Evangeline, and Jasper aquifers, Houston-Galveston region, Texas, 2019: U.S. Geological Survey Scientific Investigations Report 2019-5089, 18 p., accessed October 21, 2019, at https://doi.org/10.3133/sir20195089.

DeSimone, L.A., McMahon, P.B., and Rosen, M.R., 2014, The quality of our Nation's waters - Water quality in principal aquifers of the United States, 1991-2010: U.S. Geological Survey Circular 1360, 151 p., accessed October 21, 2019, at https://dx.doi.org/10.3133/cir1360.
Hem, J.D., 1985, Study and interpretation of the chemical characteristics of natural water (3d ed.): U.S. Geological Survey Water-Supply Paper 2254, 263 p.

Norman, J.E., Toccalino, P.L., and Morman, S.A., 2018, HealthBased Screening Levels for evaluating water-quality data (2d ed.): U.S. Geological Survey database, accessed January 23, 2020, at https://water.usgs.gov/nawqa/HBSL, doi:10.5066/ F71C1TWP.

Oden, J.H., and Szabo, Z., 2015, Arsenic and radionuclide occurrence and relation to geochemistry in groundwater of the Gulf Coast aquifer system in Houston, Texas, 2007-11: U.S. Geological Survey Scientific Investigations Report 2015-5071, 105 p., 4 apps., accessed October 21, 2019, at http://dx.doi. org/10.3133/sir20155071.

Oden, T.D., 2011, Groundwater environmental tracer data collected from the Chicot, Evangeline, and Jasper aquifers in Montgomery County and adjacent counties, Texas, 2008: U.S. Geological Survey Data Series 580, 37 p., accessed September 30, 2019, at https://pubs.usgs.gov/ds/580/.

Ryder, P.D., 1996, Ground water atlas of the United StatesOklahoma, Texas: U.S. Geological Survey Hydrologic Atlas 730-E, accessed October 21, 2019, at http://pubs.usgs.gov/ha/ ha730/ch_e/index.html.

\section{By Patricia B. Ging}

\section{For more information about NAWOA activities in Texas, please contact}

Director, Oklahoma-Texas Water Science Center

U.S. Geological Survey

1505 Ferguson Lane

Austin, TX 78754

gs-w-txpublicinfo@usgs.gov

or visit https://www.usgs.gov/centers/tx-water 